UNITED STATES DEDARTVEAT OF AGRICUITURE

BUREAU OF ENTOUOLOGY AND PIANT QUARANTINE

Wasington, D.C.

B. E. P. Q.- - 429

March 27, 1937.

PIANT-QUARANTINE INPORT RESTRICIIONS

OF THE

NETHERIANDS EAST INDIES 


\section{Digitized by the Internet Archive in 2013}


UNITED SIATES JEPARTVENI OF AGRICUITURE

BUREAU OF ENTONOIOGY AND PIANT QUAPANTINE

Mashirgton, I.C.

B. E. P. Q.--429

March 27, 1937.

\section{PLANT-QUARANTINE IIPORT RESTRICTIONS \\ OF THE \\ NETEERIANDS IAST INDIES}

This summary of the phytosanitary import restrictions of the Netherlands East Indies has been prepared for the information of murserymen, plant quarantine officials, and others interested in the exportation of plants and plent products to that colony.

It $\pi$ as prepared by Harry B. Sham, Plant Guarantine Inspector, in charge of Foreign Information Service, Division of Foreign Plant Quarantines, from his translations of the orininal and Geman texts of the Decrees of September 27, and Noveraber 3, 1926, and that of October 21, 1929, and reviewed by the Director of Agriculture, Industry and Commerce (Directeur van Iandboum, Nijverheid en Handel), of the Netherlards East Indies.

The information contained in this circular is bulieved to be correct and complete up to the time of preparation, but it is not intended to be used independently of, nor as a substitute for, the original texts, and it is not to be interpreted as legally autroritative. The decrees themselves should be consulted for the exact texts.

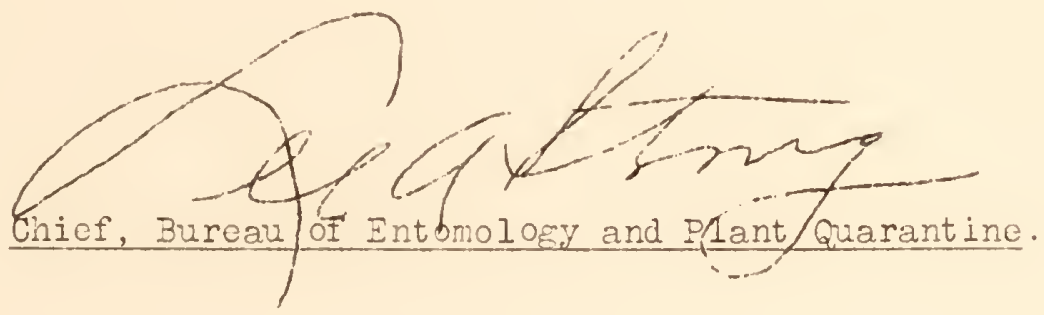


,

. .

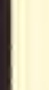

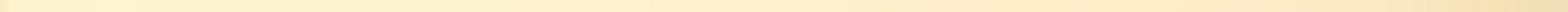




\section{PLANT-QUARANTINE IITORT RESTRICTIONS}

OF TEE

\section{NETFERIAIES EAST IIDIES}

\section{CONTENTS}

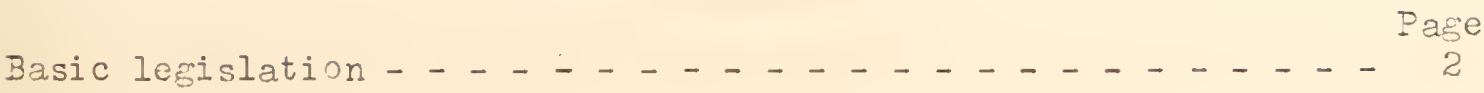

Sumnery - - - - - - - - - - - - - - - - - 2

Importation prohibited - - - - - - - - - - - - 2

Importatior restricted - - - - - - - - - - - 2

Importation unrestricted - - - - - - - - - - - 3

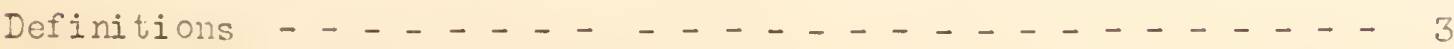

Regulations governing the importation of plants - - - - - - 3

Inportation of Fevea plants and seeds from South imerica - - - 3

Importation of other plants rostricted - - - - - - - - 4

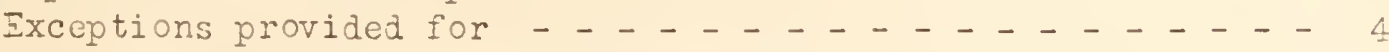

Special excmptions - - - - - - - - - - - - - - 4

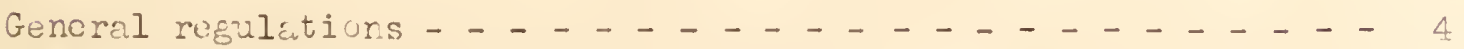

Section I. Authorized ports of entry - - - - - - - - 4

Section IV. Importation unrestricted - - - - - - - - - 5

Section $V$. Import restrictions on plant material - - - - - 8

Phytosaritery certificetc required - - - - - - - - 8

Rustrictions on the importetion of notetues - - . - . - 8

Restrictions on the importetion of Eevea - _ - . - - 9

Inspection on arrival - - . - - - - - - . - 8

Restrictions on the importation of fmits and potatoes - - - 10

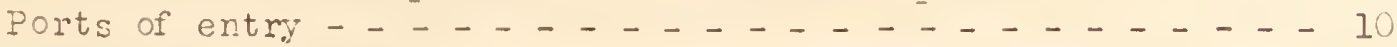

Import perrit required - $-\ldots \ldots$

Phytosnnitary certificete required - $\ldots+\ldots$

Special permit required for flax secd _ - . - . - . - - 11 
PLANT-QUARANTINE IMPORT RESTRICTIOIS

OF THE

NETHERLANDS EAST INDIES

BASIC LEGISLETION

Iaw of September 27, 1026, article 2 (Stantsblad von Ned. Indie No. 427).

\author{
STMNARY
}

Importation Prohibited

HEVEA BRASIIIENSIS, IIVING PLANTS ATD PARTS THEREOF FRON SOUTH HVERICA. (Law of Sept. 27, 1926, as amended by that of oct. 14, 1932.)

\title{
Importation Restricted
}

HEVEA BRASILIENSIS: THE SEEDS may be imported from South America only under a special authorization from the Director of Agriculture, Industry and Commerce. (Decree of Sept. 27, 1926, as amended by that of Oct. 14, 1932.)

HEVEA BRASILIENSIS Mïl. Arg. SEEDS, IIVING PLANTS AND PARTS THEFEOF I rom countries other than South America: Certificate of the phytopatiological service of the country of origin affirming that the trees irom which this material was obtained are free from Fusicladium macrosporum Kuyper, Phytophthora faveri Naubl., and Phytophthora meadi McPae. (Section $V$, article $1(3)$, Decree of Nov. 3, 1926.)

- IANT MATERIAI OTHER THAN THAT ITENIZED IN SECTION IV of the Decree of November 3, 1926: Phytosanitary certificate by a competent official of the Government (or one of the branches thereof) of the country of origin. (Section V, article 1, Decree of Nov. 3, 1926.) (See p. 8.)

POTATOES from Netherlands, Germany, Belgium, Poland, Great Britain and Ireland, Canada, and the United States: Certificate of competent autrority of country of origin affirning that the potatoes have been found free from wart, (Synchytrium endobioticum (Schilb.) Perc.) and that this disease does not occur in the field where the potatces were grown nor within a radius of 500 meters therefrom. (Section $V$, article 1 (2), Decree of Nov. 3, 1926, and the Decree of Oct. 21, 1929.) (See pp. 8 and 10.) 
PIANT MATEIAL FRON CHINA: No certificate of competent authority required, but the shipment will be subject to inspection on arrival. (Section $\mathrm{V}$, article 1 (4), Decree of Nov. 3, 1925.).

FRITS FROI. FOREIGN COUNTRIES (EXCEPT CHINA): Wust be accompanied by a certificcte issued by competent outhority of the country of origin affirming frecdon from pests nnd discases of cultivated plants; inspection on arrival and release only on issunce of an import permit. (Decrew of October 21, 1929.) (See p. 10.)

FRUITS ASSEIBIED IN THE NETHERTANDS for export to lietherlands East Indies: Phytosanitnry certificnte issued by the Phytopnthological Service of the Netherlands. (Section V, article 1 (5), Decrec of Nov. 3; 1926.)

CACAO PIANTS (Theobroma ceceo I.) FRCM ANEPICA: Declarntion by conpctont wutiority of country of origin thet thuy wire grown in Europe in European soil from seeds produced in Americn. (Section $V$, article 1 (6), Decree of November 3, 1926.) (Soe p. 9.)

FLAXSEED (Iinum usithtissimum): Specinl pormit required for its importrtion. (Decree effective Jan. 1, 1934, p. 11.)

Importation Unrestricted

PLANT MATERIAL ITEN IZED IN SECTION IV of the Decree of November 3, 1926. $($ Sec $p .5-8$.

\section{Definitions}

1. "Plant material" shall include sceds, fresh fruits, living plants, and parts thereof.

2. "Director" signifies the Director of Agriculture, Industry, and Commerce of the Nictherlonds East Indies.

REGUIATIONS GOVERIING TEE IMPOETAIION

OF IIVIAG PIAINT MATERIAI

TO PREVENT THE INTRODUCIION OF PIANT DISEASES AND PESTS

(Decree of the Governor-General, Sept. 27, 1926; Staatsblad van Nederlandsch-Indie, No. 427, 1926)

Importation of Hevea Plants and Seeds from South Anerica

Article 1. Concerns the importation of Hevea plants and secds from 


\section{Importation of Other Plants Restricted}

Art. 2. (1) The importation of living plont material, other than that referred to in article I (without prejudice to the provisions of articles 4 and 7 ) is permitted only through the ports authorized for that purpose by the Director and with duc observance of the provisions promulgated by him.

Art. 3. prescribes that the importer shall pay inspection fees.

\section{Exceptions Provided For}

Art. 4. Under conditions to be imposed by him, the Director may permit the importation into the Netherlands East Indies of plant material such as that referred to in article 2 , in respect to which the provisions of this decree have not been observed.

Art. 5. Provides for penalties for infractions of the regulations.

Art. 6. Provides for the appointment of officials charged with the detection of infractions.

\section{Special Exemptions}

Art. 7. This decree does not apply to the importation of:

(a) Living plant material for the importation of which special regulations are or vill be estaolished;

(b) Seeds obviously intended for corsumption;

(c) Living plant material to be indicated by the Director.

\section{GENERAL, PEGULATIOAS}

(Decree No. $9760-$ A.Z., Nov. 3, 1926, as amended)

\section{SECTION 1. AUTHORIZED PORTS OF ENTRY}

Article 1. The Director has resolved to designate the following as ports of entry:

(a) For seeds, living plants, and parts of living plants Tandjoeng Priok, and Medan (Belawan Beli).

(b) For fresh fruits by mail: Tandjoeng Priok, Semarang, Soe rabaja, Sabang, Oelee Lheue, Padnng, Benkoelen, Palemoang, Djambi, Rengat, Bengkalis, Medan (Belavan Beli), Inng- 
kolpinang, Tandjoeng, Panden, Pontinnnk, Iingkas (Tarnkan),* Samarinda, Bolilipapan, * Manado, Nakassar, and Boela.

(c) For potatoes by mail: Tandjoeng Priok, Wedan, Iingkas (Tarakar), * 3alikpapan,* and Manado.

(d) For tea seeds: Tandjoong Priok, Kedan, Palembang, and Padang.

(e) For plant material intended for experiments of the cocomut Experiment Station at Vanado: Nanado.

Sections II and III. Concern the appointment of technical inspectors.

\section{SECTION IV. IIPORTATION UNRESTRICIED}

Living plart material to which the provisions of the Decrec of Soptenber 27, 1926, are not applicable:

(a) Soeds of the followirg-named vegetables, herbs, fruits, and medicinal plants:

Alliun spp.: chive, garlic, leek onion, shallot, etc.

Anetruin graveolers I., dill

Anthriscus cerefolium Hoffm., chervil

Artumisia abrotanu? L., southernwood

Asparanus oficinalis L., asparagus

Brassica sp.: broccoli, cabbage,

cauliflover, kale, mustard,

mutabasa, turnip, etc.

Capsicum annum $I$., red pepper

Cichoriur intybus I., chicory, vitloof

Cochlearia officinalis I., scurvy grass

Coriandrur sativam I., coriander

Cynara scolymus I., globe artichoke

Daucus carota I., carrot

Foeniculun vilsare Hill, fennel

Fragaria so., stramberries

Lactuca sativa I., lettuce

Lavandula (officinalis) vera D.C., lavender

Leontodon, see Taraxacum

Lepidium sativum I., peppergrass

Lycopersicum esculentum Mill, tomato

Melissa officinalis I., balm

Mentha spo., mints

Jcimum basilicum I., basil

Oriomur ma.jorana I. , marjoram

Pastinaca sativa $I$., parsnip

Pimenta officinalis Berg., allspice
Pimpinella anisum I., enise

Portulaca oleracea I., purslane

Radicula amoracia Robins, horseradish

Radicula nasturtium-aquaticum Brit. Rend., watercress

Raphamis sativus $I$., radish

Pheum rhaponticum L., rhubarb

Ribes spp., currants and gooseberries

Rosmarinus officinalis L., rosemary Rubus spp., blackberries, raspberries Ramex spp., sorrel

Salvia spp., sage

Satureia spp., savory

Scandix - see Anthriscus

Scorzonera hispanica I., salsify

Sinacis - see Brassica

Sisymbrium - see Radicula nasturtiuaquaticum

Solanum melongena I., eggplant

Spinacea oleracea $I$., spinach

Taraxacum officinale Teber, dandelior.

Tetragonia expansa Thunb., Ner Zealand spinach

Thymus vilgaris I., thyme

Valcrianella olitoria ivench, cornsalad

* Only the ports of Balikpapan and Iingkes (Tarakan) are authorized for the ontry of commercial shipmcrts. (Sco Decree of Oct. 21, 1929, p. 1.) 
(b) Seeds of ornamental plants bolonging to the following genera:

Abutilon
Adonis
Ageratum
Agrostema.

Al thae?

Alys surn

Anaranthus

Ammobium

Anemone

Antigonon

Antirrininum

Aquilegia

Arctotis

Aristolochis.

Asparagus

Aster

Beร̃oni?

Bellis

Bidens

Boltonia

Boussingaultia

Buphtha.linum

Cacalia

Calceolaria

Cartenalua

Campanula

Canna

Carduus

Celosia

Centauria

Cheiranthus

Chrysanthemum

Cineraria

Clarkia

Clematis

Clerodendron

Cobaea

Coleus

Convolvulus

Coreopsis

Cosmos (Cosmea)

C'xphea

Cyclamen

Cynara

Cynoglossum

Dahlia

Lelphinium

Diantrus

igitalis
Dimo rphotheca

Eccrenocarpus (Calampelis)

Eschscholtzia

Gaillardia

Gerardia

Gerbera

Gilia

Gloxinia

Gomphrena

Gyos ophila

Helianthus

Helichrysum

Feliotropiun

Helipterum (Acroclinium, Rhodanthe)

Hibiscus

Iberis

Impatiens

Inula

Ipomoea

Kniphofia (Tritonia)

Leptosiphon

Iinaria

Iobelia

Iunaria

Iychnis

Matricaria

Matthiola

Maurandia

Mediola

Minulus

Nirobilis

Nyosutis

Nemesia

Nenophila

Nicotiana

Nírella.

Nycterinia

Oenothern

Passiflora

Pelargonium

Pentstemon

Perille.

Petunia

Phocelia

Phlox

Physelis

Poinsettin

Portulaca

Potentilla 
Primuls

Pyrethrua

Quanoclit (Mina)

Reseda

Ricinus

Rosa

Rudbeciria

Salpiossis

Salvia

Sanvitalia

Saponaria.

Scabiasa

Schizantrus

Senecis

Silene
Solanum

Stevia

Stokesia

Streptocarpus

Tasetes

Thelesperma (Cosmidium)

Thunbergia

Tithonia

Torenia

Tracheliutn

Iropaeolum

Verbena

Vinca (Iochnera)

Viola

Volutarella (Amberboa)

Zinnia

(c) As anended by Decree Ko. 7345-A, August 12, 1929 :

1. Veretables, onions, bulbous plants (except potatoes), beets, and root crops intended for consumption or redicinal pirmoses;

2. Shallots and garlic;

3. Dried fruits and parts thereof, such as almonds, peanuts, Erain, chestnuts, caramay seeds, clores, Jesuit's nut (Irapa bicornis I., I. natans I., ling-kok), mutmegs, malnuts, palrwo, pepper, rice, etc., for consumption or medicinal purposes.

(d) Coconuts from which the husks have been removed.

(e) Spann of edible mushrooms.

(f) Susarcane cuttings imported through Tandjoenk Priok and Soerabaja for scientific curposes and addressed to the Director of the Experiment Station of the Java Sugar Industry at Pasoerocan.

SECTION V. IMPORT RESTRICTIONS ON PIANT MATERIAI

With respect to the permissible importation of living plant material into the Netherlands East Indies, the folloning provisions are applicable: 


\section{Phytosanitary Certificate Required}

Article 1. (1) Tho importation of the plant material referred to in article 2 of the Decree of September 27, 1926 (except as indicnted in the folloming paragraphs) is peritted only when each sinipert is acco:panied by a cortificate signed by a cornpetent official of tire govermint of the country of orisin or one of the branches thereof.

(a) Indicnting the spocies to which the plant moterinl belongs or from which it vas derived;

(e) The quantity and weight thereof;

(c) Affirning trat at the time of shipment the said material was, according to his conviction, free from pests and diseases of cultivated plants.

\section{Restrictions on the Importation of Potatoes}

(2) Fithout prejudice to the provisions of the preceding paragraph, the importation of potatoes from the Nietherlands, Germany, Belgium, Poland, England and Tales, Ireland, Scotland, United States, and Canada is permitted only when each shipment is accompanied by a certificate issued by an official phytopathological institution of the country of origin affirming that tho potatoes were found free from mart disease (S.ynchytrium endobioticum (Schilb) Ferc.), and that this disease does not occur in the field in which the potatoos vere grown, nor within a radius of 500 meters therefrom. (See also the Decree of Oct. $21,1929, \mathrm{p} .10$. )

\section{Restrictions on the Importation of Hevea}

(3) Tithout projudice to the provisions of paragraph 1 of this article, the importation of seeds, living plants and parts thereof of Hevea brasiliensis is permitted only when the shipment is accomparied by a certificate issued by the phytopathological institute of the country of origin, affiming tiat the trees from which the plant matericl was taken are free from the South American leaf disease (Wulanopsammopis ulei (Henn.) Stahel) = (Fusicladiun macrosporium Kuyper) and from phytophthora leaf-fall. diseases (Phytophthora faberi Maube. and P. meadi McRae), and that on the estate or estates there the said trees grew no material has ever beer imported from countries where these discases occur.

Parasraphs 4, 5, and 6, ruspectively, of this article provide (1) that plant material may be imported from china without the certificate prescribed by parasraph 1; (2) that fruits assembled in the Netherlands may 
bo imported if accompanied by a certificate issued by the phytopathological survice at Tageninger; (3) that cacao plants (Theobroma cacao) from Anerican may be imported only in the forn of living cacao plants from from seed ir Europe in European soil.

\section{INSEZCIION ON ARRIVAL}

Art. 2. (1) The plant material referred to in the proceding article, and the containers, and packing material in which it was imported, will be allomed to proceed to the consigree only after having been inspected by the expert mentioned in sections II and III, and found to be free from pests and diseases of cultivated plants; or if that be practicable, after it has beer disinfected or otherwise frecd from the organisms concerned.

Articles 3,4, 5, and 6. Concern the disposal of shipments of plant material on arrival.

SECTIOI VI. Fees for inspection and disinfection.

SECIION VII. Exemption of shipments of plant material intended for the Department of Arriculture, Industry, and Commerce and institutions conrected with that department.

SECIION VIII. Irescribes forms for import permits, reports of seizure, etc.

\section{RESTRICIIONS ON TFE IEPORIATICN OF FRITS AND POTATUES}

\section{(Decrze of Oct. 21, 1929)}

The iollowing provisions have been promulgated by the Director of Asriculture, Industry, and Comerce, Buitenorg, by Decree No. 9660-A, October 21, 1929, for the importation of fresh fruits and potatoes.

\section{Ports of Entry}

A. Without regard to mail shipments of fresh fmits and potatoes, to vinich the provisions of the Decree of November 3, 1926 , romain applicable, the ports of Balipapan and Iingkas (Tarkkan) are designated as ports of entry for fresh fmits and potatoes. 
B. The following regulations apply to the importation of the products named in A through the placus named therein.

\section{Import Permit Fequired}

Article 1. Fruits and potertoes aro admitted into unrestricted traffic after a permit has been issucd by the chief official of the Import and Export Customs and Tariff Service, or in his name.

\section{Phytosanitary Cortificate Required}

Art. 2. This pernit wil] be issued only when the fruits and potatoes offered for ertry are accompanied by:

(a) A certificate signed by an expert of the government of the country of origin or one of its organizations, in which is indicated the kind and quantity (number of packages), itemized as far as necessary, and affiming trat the fruit or potatoes contained in the shipment, according to his inspection, we ro free from pests and diseases of cultivated plants.

(b) With respect to potatoes, in addition, a certificate issued by a phytopathological institution in the country of origin in which it is affirmed that the potatoes were found free from potato wart (Synchytrium endobioticum) and that in the field in which the potatoes viere grom and for a radius of $500 \mathrm{~m}$. this disease does not occur.

(c) A declaration of the phytosanitary official in charge of the national phytosanitary service in the locality or, in his absence, of the physician of the Batavian Petroleur: Company (Bataafsche Petroleum Maatschappij) to the effect that he inspected the shipment and deemed the fruits and/or potatoes fit for entry.

Art. 3. The declaration under 2 (c) is not to be furnished by the physician concerned for fmits and/or potatoes which on inspection show:

(a) 1. With respect to fmits, that these or their packing material are not free from living stages of fmit flies or fresh traces of those insects.

2. With respoct to potatoos, that they are not free from vart.

(b) That they are found to be in such a dying condition, or so rotten, that it is not possible to make an inspection for the presence of the pests named under (a). 
Art. 4. Fruits and/or potatoes rot deemed fit for incertation by the insuecting physician will be destroyea.

\section{Special Permit Pequired for Flaxseed}

The importation of seeds of plants of the gemus Iimu is permitted only under a special permit Eranted by the Iirecter of Asriculture under srecial conditicns tc be imposed in each case. (Flaxseed is known also as linseed and birdseed and pharnaceutically as Seren Iini.) (Focree effective Jan. I, I934.) 
UNIVERSITY OF FLORIDA

31262092422004 